\title{
Multiple cranial nerve palsies secondary to a recurrence of Hansen's disease
}

\author{
Preet Mukesh Shah, ${ }^{1}$ Vijay Waman Dhakre, ${ }^{2}$ Abhijeet Prasad ${ }_{1}^{3}$ Pratit Samdani ${ }^{3}$
}

'Department of Critical Care, Jaslok Hospital and Research Centre, Mumbai, Maharashtra, India

2Department of Liver Diseases, HPB Surgery and Transplantation, Global Institute of Liver Diseases, Mumbai, Maharashtra, India ${ }^{3}$ Department of General Medicine, Jaslok Hospital and Research Centre, Mumbai, Maharashtra, India

\section{Correspondence to} Dr Preet Mukesh Shah, drpreetshah@gmail.com

Presented as a poster at APICON 2017

Accepted 31 December 2017

\section{CrossMark}

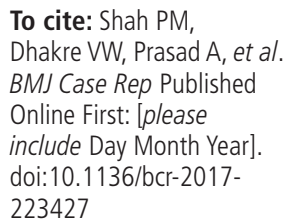

\section{DESCRIPTION}

A 31-year-old Indian man presented with drooping of the right eyelid since 1 month, slight deviation of the angle of the mouth to the right since 20 days, difficulty in swallowing (initially with regard to solids, and later on with regard to liquids) since 15 days, nasal regurgitation since 15 days and a nasal twang since 15 days. His past history was not significant, with no history of fever, weight loss, diarrhoea, swollen glands, rash, disfigurement of the hands and feet, loss of eyebrows, or any history suggestive of limb weakness, numbness or tingling. He was not on any medications. None of his parents had any health problems.

He had been previously treated for multibacillary leprosy (Hansen's disease) 3 years back and had taken treatment for 1 year for the same.

On examination, he was found to have bilateral lower motor neuron (LMN)-type glossopharyngeal and vagus nerve palsy; right-sided oculomotor nerve palsy as evidenced by right eye ptosis, with the right pupil being constricted and non-reactive, and with the extraocular movements bilaterally equal in all directions; and left-sided LMN-type facial nerve palsy. None of his peripheral nerves were thickened.

Complete blood count, erythrocyte sedimentation rate, $\mathrm{C}$ reactive protein, blood sugar level, serum ACE levels, anti-nuclear antibodies, electromyography-nerve conduction velocity studies and cerebrospinal fluid examination were all within normal limits. HIV ELISA was negative. MRI of the brain was normal.

Positron emission tomography-CT scan was done which showed metabolically active bilateral level IV cervical, mediastinal, bilateral hilar and peribronchial lymph nodes, left common iliac

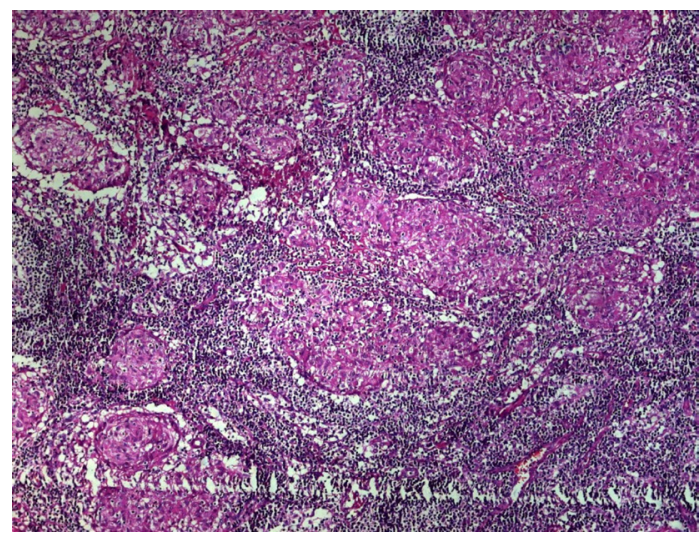

Figure 1 Lymph node histopathology section showing diffuse and confluent tubercles without caseous necrosis.

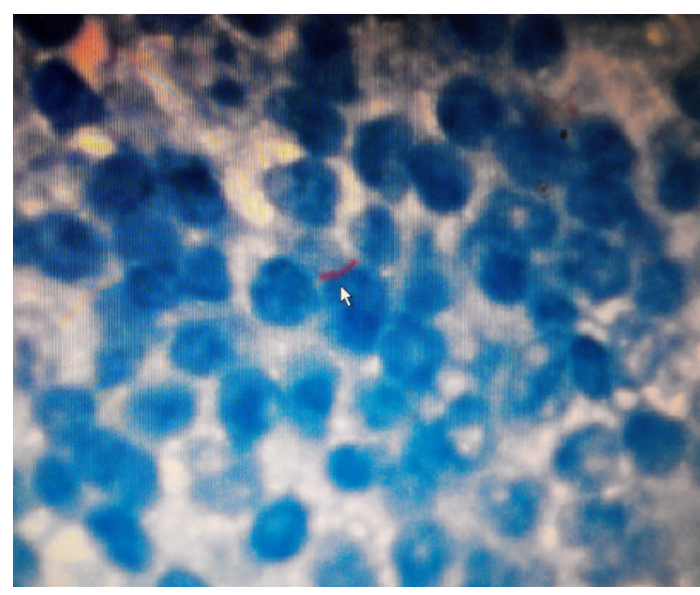

Figure 2 Fite-Faraco staining of the tissue sample showing one stout bacillus (white arrow).

adenopathy, and multiple lung nodules. These findings suggested sarcoidosis/lymphoma.

Excisional biopsy of the right supraclavicular lymph node was done, and the histopathology section showed diffuse and confluent tubercles, with no caseous necrosis (figure 1). Fite-Faraco staining of the tissue sample was done and revealed one stout bacillus (figure 2). Tissue culture and TB-PCR (GeneXpert) test were negative for tuberculosis. These findings were suggestive of lepromatous lymph node involvement.

He was started on pulse therapy with methylprednisolone, after which his clinical features improved, and then he was put on rifampicin, dapsone and prednisolone. Gradually his features completely abated.

Cranial nerves may be involved in leprosy, and usually the facial, olfactory and the trigeminal nerves are the ones that are commonly involved, with other cranial nerves being less commonly involved. ${ }^{1}$ A majority of the cases of leprous cranial neuropathy have features such as resorption of digits, madarosis and trophic ulcers. ${ }^{2}$

Our case was unusual since the patient did not have these additional features, and only had features suggestive of involvement of the oculomotor, facial, glossopharyngeal and vagus nerves.

\section{Patient's perspective}

"I never thought that my complaints could be due to the condition that I had 3 years back, since I had been cured from it. I thought it was something else. I should have gone to the doctor the moment the problem started." 


\section{Learning points}

Hansen's disease can be a cause of multiple cranial nerve palsies, especially in India. This should be considered in a patient with a history of Hansen's disease.

- Cranial nerve involvement may occur in isolation, without the involvement of peripheral nerves.

- Leprous cranial neuropathy may occur in the absence of madarosis, trophic ulcers or resorption of digits.

- Positron emission tomography-CT scan is useful in guiding management in such cases, which are diagnostically challenging, and the scan may help identify the nodes that are actively affected by the disease.
Contributors PMS wrote up the case details. VWD assisted in the discussion of the case. PS was the treating physician and also assisted in the discussion of the case. AP procured the clinical photographs of the patient.

Competing interests None declared.

Patient consent Obtained.

Provenance and peer review Not commissioned; externally peer reviewed.

(C) BMJ Publishing Group Ltd (unless otherwise stated in the text of the article) 2018. All rights reserved. No commercial use is permitted unless otherwise expressly granted.

\section{REFERENCES}

1 Gopinath DV, Thappa DM, Jaishankar TJ. A clinical study of the involvement of cranial nerves in leprosy. Indian J Lepr 2004;76:1-9.

2 Kumar S, Alexander M, Gnanamuthu C. Cranial nerve involvement in patients with leprous neuropathy. Neurol India 2006;54:283-5.

Copyright 2017 BMJ Publishing Group. All rights reserved. For permission to reuse any of this content visit http://group.bmj.com/group/rights-licensing/permissions.

BMJ Case Report Fellows may re-use this article for personal use and teaching without any further permission.

Become a Fellow of BMJ Case Reports today and you can:

- Submit as many cases as you like

- Enjoy fast sympathetic peer review and rapid publication of accepted articles

- Access all the published articles

- Re-use any of the published material for personal use and teaching without further permission

For information on Institutional Fellowships contact consortiasales@bmjgroup.com

Visit casereports.bmj.com for more articles like this and to become a Fellow 